\title{
Biografi sebagai Pintu Masuk Mencermati Peristiwa Remeh Temeh Sehari-Hari dalam Revolusi Indonesia (1945-1949) di Bali
}

\author{
I Nyoman Wijaya \\ Program Studi Ilmu Sejarah, Fakultas Ilmu Budaya, Universitas Udayana \\ Jl. Pulau Nias, Dauh Puri Klod, Denpasar - Indonesia \\ "Alamat korespondensi: iwijayastsp@yahoo.co.id \\ DOI: https://doi.org/10.14710/jscl.v5i1.28822
}

Diterima/Received: 2 Maret 2020; Direvisi/Revised: 26 Maret 2020; Disetujui/Accepted: 15 April 2020

\begin{abstract}
This study discusses biography as an entry point to talk about trivial everyday events taking place during Indonesia's physical revolution (1945-1949) in Bali. If in the arena of guerrilla warfare trivial everyday stories can be seen, what about outside the arena? Starting from this central question, this study will attempt to see trivial everyday events in Indonesia's revolution in Bali, especially events taking place outside the arena of guerrilla warfare. Those events, however, do not stand alone, but they are entwined with Indonesia's revolution in Bali. Outside the arena of guerilla war, those trivial everyday events can be seen in each stage of Indonesia's revolution in Bali distributed in various villages. The research results indicate that biographical figures born in the 1930s, aged from 11 to 15-year-old, during the period of guerrilla warfare managed to retell those trivial events. Even though not directly involved in the guerrilla warfare, they were able to provide information about those events, because some of them were actively involved as mail couriers connecting the fighters and their families. Most of the information they provided has not been recorded in the grand narrative of the history of Indonesia's physical revolution in Bali.
\end{abstract}

Keywords: Physical Revolution; Trivial Events; Guerilla War.

\begin{abstract}
Abstrak
Studi ini menganalisis biografi sebagai pintu masuk untuk membicarakan peristiwa remeh temeh sehari-hari yang terjadi dalam Revolusi Fisik Indonesia di Bali. Jika di arena perang gerilya saja masih terbaca kisah sehari-hari yang remeh temeh, lalu bagaimana halnya dengan di luar? Berangkat dari pertanyaan sentral ini, maka studi ini mencoba melihat peristiwa kecil sehari-hari yang remeh temeh dalam Revolusi Indonesia (1945-1949) di Bali. Hasil penelitian menunjukkan tokoh biografi kelahiran 1930-an, yang berusia sekitar 11 sampai dengan 15 tahun di masa perang gerilya mampu menceritakan kembali peristiwa remeh temeh sehari-hari tersebut. Sekalipun tidak terlibat secara langsung dalam perang gerilya, namun mereka mampu memberikan informasi seputar peristiwa tersebut. Hal itu karena sebagian dari mereka terlibat aktif sebagai pembawa surat yang menghubungkan para pejuang dan keluarganya. Informasi yang mereka berikan sebagian besar belum tercatat dalam narasi besar sejarah Revolusi Fisik Indonesia di Bali. Dengan menggunakan metode sejarah, pada penelitian ini dikaji mengenai relasi kuasa pengetahuan yang terkuak dari cerita tokoh-tokoh tersebut. Adapun tujuan dari penelitian ini adalah untuk menyatukan serpihan-serpihan cerita selama masa Revolusi Fisik yang masih tercecer karena sebagian besar sejarawan hanya fokus pada cerita-cerita besar yang dianggap sentral.
\end{abstract}

Kata Kunci: Revolusi Fisik; Remeh Temeh; Perang Gerilya.

\section{Pendahuluan}

Kondisi politik Bali pada awal tahun 1950-an ditandai dengan terjadinya perseteruan antara Partai Sosialis Indonesia (PSI) dan Partai Nasional Indonesia (PNI) (Dwipayana, 2004: 86). Di sisi lain, pada periode itu para elite politik di Bali sibuk melakukan pembenahan, berusaha menyembuhkan rakyat dari trauma masa Revolusi Indonesia (1945-1949), yang di Bali lebih dikenal dengan sebutan Revolusi Fisik. Pada November 1949 di Buleleng berlangsung per-temuan yang melahirkan 
organisasi Lanjutan Perjuangan. Organisasi ini merupakan hasil peleburan Markas Besar Istimewa (MBI) dan Gerakan Rakyat Indonesia Merdeka (GERIM). MBI adalah organisasi 'bawah tanah' yang melanjutkan perjuangan laskar Bali setelah I Gusti Ngurah Rai gugur dalam Perang Margarana, 20 November 1946, di bawah kepemimpinan Ida Bagus Tantra (Poleng).

Sebagai ketua MBI, Tantra dipilih menjadi ketua organisasi Lanjutan Perjuangan, dibantu oleh Santosa sebagai wakilnya, Ida Bagus Tamu (Tanaya) dan Nengah Tamu (Tjilik) sebagai ketua dan wakil di bidang pertahanan. Sesuai namanya, organisasi ini bertujuan untuk melanjutkan perjuangan (Revolusi Fisik) demi terwujudnya cita-cita bangsa dan Tanah Air berdasar Proklamasi 17 Agustus 1945. Pada 4 Januari 1950 nama organisasi Lanjutan Perjuangan diganti menjadi Pemerintah Darurat Republik Indonesia (PDRI). Di bawah perintah Tantra, pada 15 Januari 1950, semua anggota $\mathrm{MBI}$ turun dari gunung-gunung untuk bergabung dengan PDRI guna 'membangun negeri.' Mereka lalu membentuk Batalyon Arjuna TNI Bali (Pendit, 2008).

Namun karena ketidakcermatan Ketua Komisi Militer Kapten Andi Yusuf dalam bertindak, maka terjadi pergesekan antara orangorang PDRI dengan Dewan Perjuangan Rakyat Indonesia, Bali (DPRI). DPRI adalah wadah perjuangan para pemuda gerilya di masa Revolusi Fisik. Setelah peristiwa Revolusi Margarana, 20 November 1946, maka satu per satu anggota DPRI yang masih hidup ditangkap dan menyerahkan diri. Mereka lalu dipenjara. Sekalipun mereka telah melakukan penyerahan umum, namun Kapten Andi Yusuf tidak membubarkannya. Setelah keluar dari penjara mereka lalu berhadapan dengan PDRI, beranggotakan orang-orang tidak mau menyerah kepada Belanda dan memilih melanjutkan perjuangan melalui MBI di bawah kepemimpinan Tantra.

Mengingat keberadaan organisasinya belum dibubarkan, orang-orang DPRI masih merasa memiliki hak memimpin perjuangan "membangun negeri”. Namun mereka berhadapan dengan PDRI yang sekalipun belum disahkan, namun secara de facto, dalam kenyataannya merupakan wakil perjuangan rakyat Bali yang sah. Setelah era Komisi Militer berakhir, pertentangan tajam antara PDRI dan DPRI melahirkan tragedi. Diawali dengan keputusan pemerintah pusat membentuk tiga kompi serdadu alat-alat kekuasaan Belanda (KNIL) menjadi Angkatan Perang Republik Indonesia Serikat (APRIS). Akibatnya banyak mantan tentara KNIL yang secara sah diangkat menjadi anggota APRIS. Keputusan ini dinilai oleh DPRI sama sekali tidak memperhitungkan aspirasi daerah.

Kondisi tahun 1950-an itu merupakan patahan atau retakan dari peristiwa yang terjadi sebelumnya, periode Revolusi Fisik 1945-1949. Narasi besar mencatat, perjalanan Revolusi Fisik di Bali dapat diperas dalam empat babak, yakni persiapan, kedatangan Sekutu dan pendaratan NICA, perang gerilya, dan menyerah-meneruskan perlawanan.

Babak pertama terjadi setelah insiden penurunan bendera Belanda di Buleleng. Diawali dengan kedatangan kapal 'Abraham Grijns' berbendera Belanda tiba di Pelabuhan Buleleng pada 25 Oktober 1945. Para hari ketiga, terjadi saling turun menurunkan bendera. Dalam peristiwa ini seorang pemuda pejuang tewas karena terkena tembakan senjata api dari atas kapal. Setelah kapal Abraham Grijns meninggalkan Pelabuhan Buleleng, para pemuda pejuang mulai melakukan berbagai persiapan untuk menyambut kedatangan Belanda, antara lain pada 13 Desember 1945 merebut senjata di tangsi-tangsi militer Jepang, namun gagal.

Babak kedua kedatangan Sekutu dan pendaratan NICA. Tentara Sekutu datang pada 16 Februari 1946 di Pelabuhan Benoa, Badung. Dan disusul oleh pendaratan Kapal Gajah Merah di Pantai Sanur pada 2 Maret 1946 yang menurunkan satu kesatuan alat pemerintah sipil Hindia Belanda, disebut Nederlandsch Indië Civil Administratie atau Netherlands-Indies Civil Administration (NICA). Jadi, NICA tidak 'dibonceng' dalam pengertian harfiah oleh Sekutu, melainkan hanya di-backing dari Pelabuhan Benoa.

Babak ketiga Perang Gerilya. Langkah pertama yang dilakukan Pasukan Gajah Merah menduduki semua daerah di Bali mulai dari Denpasar, Gianyar, dan seterusnya. Pada 11 Maret 1946 NICA mengadakan perundingan dengan para pejabat pemerintahan Republik Indonesia Sunda Kecil di Singaraja yang berlanjut dengan penangkapan dan penurunan bendera Merah Putih. Bersamaan dengan itu barisan Pemuda 
Pembela Negara (PPN) bentukan Raja Gianyar, Ide Anak Agung Gde Agung, menyatakan bekerja sama dengan NICA. Situasi semakin genting. Mulai 12 Maret terjadi perang gerilya secara seporadis terutama di daerah pegunungan. Berakhir dengan kekalahan pasukan Ciungwanara di bawah pimpinan Letkol I Gusti Ngurah Rai dalam perang di lahan terbuka pada 20 November 1946. Jadi revolusi melalui jalur militer di Bali hanya berlangsung selama delapan bulan.

Babak keempat, menyerah-meneruskan perlawanan. Pada awalnya ada keputusan dari Dewan Perjuangan Rakyat Indonesia (DPRI) Sunda Kecil untuk melanjutkan perjuangan melalui jalur militer dan sudah sempat mengirim kurir ke Jawa untuk memohon bantuan. Akan tetapi, hasil Konperensi Denpasar dan Persetujuan Linggarjati melemahkan langkah-langkah tersebut. Mereka dihadapkan pada dua pilihan antara menyerah atau melawan yang disebut oleh NICA sebagai perusuh dan perampok. Para pemuda pejuang terpecah jadi dua: ada yang menyerah kepada Dewan Raja-raja di Bali dan melanjutkan perjuangan. Sementara itu, kelompok yang masih mengadakan perlawanan mendirikan markas perjuangan baru disebut Markas Besar Istimewa (MBI). "Istimewa" yang dimaksud adalah tidak sepenuhnya berperang memakai taktik militer, tetapi juga "berkomunikasi" dengan alam gaib.

Narasi besar sedemikian rupa dapat dibaca dalam karya monumental Nyoman S. Pendit (2008) yang dalam batas-batas tertentu ditemukan pula pada karya Anak Agung Bagus Wirawan (2012) dan Robinsom (2006). Sebelumnya ada karya Ida Bagus Rama (1981), namun tidak terpakai dalam Wirawan (2012) yang lebih menukik pada struktur organisasi perjuangan dalam Revolusi Fisik di Bali 1945-1950, sehingga tampak sedikit berbeda dari dua karya sebelumnya. Lebih berbeda lagi adalah karya I Gusti Ngurah Pindha (2012), seorang aktor, pelaku dalam Revolusi Fisik di Bali. Dalam buku ini Pindha membicarakan perang dari dalam tubuhnya sendiri. Di dalamnya antara lain disebutkan para pemuda pejuang bukan hanya berperang dan berperang, namun ada juga sisi lainnya mengenai kecantikan seorang gadis desa, keluguan para gadis desa, serta taktik dan strategi para mata-mata NICA, yang dapat disebut sebagai kisah sehari-hari yang remeh temeh dalam Revolusi Fisik. Akan tetapi, karya-karya yang menyebut kisah remehtemeh itu jumlahnya sangat sedikit, lagi pula tidak ada satu pun di antaranya yang mampu memberikan informasi mengenai peristiwa remeh temeh sehari-hari di luar arena perang.

Cerita mengenai peristiwa remeh temeh sehari-hari (narasi kecil) ditemukan dari informasi para pemuda kelahiran tahun 1930-an di berbagai desa di Bali. Di Desa Sanur misalnya, begitu terdengar adanya rencana penyerangan terhadap tangsi militer Jepang di Kayumas, Denpasar pada 15 Desember 1945, sejumlah laki-laki usia belia dan dewasa berkumpul di depan Griya Jero Gde Sanur, rumah brahmana lokal. Di zaman kerajaan hingga awal masa kolonial, rumah ini merupakan tempat tinggal dari salah seorang punggawa Kerajaan Badung. Mereka datang dari berbagai banjar yang ada di Sanur, dengan membawa senjata-senjata tajam milik masing-masing.

Hal yang serupa terjadi pada 1906 dalam Perang Badung melawan tentara kolonial Belanda. Dengan tidak adanya perlawanan dari rakyat Sanur, tempat dimana kapal perang Belanda berlabuh, maka Raja Badung mengerahkan pasukan dari Denpasar menuju Tanjung Bungkak (sekitar dua kilometer sebelah barat Sanur) pada 15 September. Menurut I Tunas alias Pan Redep, seorang saksi sejarah Perang Badung 1906, begitu terdengar bunyi dentuman meriam di Pantai Sanur, kelian banjar meneruskan perintah kerajaan kepada warganya. Orang-orang yang sudah berumur 10 tahun ke atas diminta datang ke bencingah, halaman depan Puri Denpasar pada 16 September 1906. Mereka wajib membawa tombak dan perlengkapan perang lainnya. Pada 16 September itu sekitar 2.000 orang berkumpul di depan Puri Denpasar.

Latar belakang di atas menunjukkan ada suatu permasalahan menarik untuk diteliti, yakni para pemuda usia belia 11-15 adalah sumber informasi untuk menggambarkan peristiwa remeh temeh sehari-hari di luar arena Perang Revolusi Kemerdekaan Indonesia (1945-1949) di Bali, sehingga dapat menutupi keterbatasan narasi besar historiografi Indonesia dalam soal ini. Di balik informasi itu ada titik temu antara peristiwa masa lalu dan masa kini. Pada 1906 massa berkumpul di puri (istana kerajaan), sedangkan pada 1946 dalam 
kasus Sanur massa berkumpul di Jero Gede (rumah punggawa Kerajaan Badung). Hal itu memerlihatkan ada relasi kuasa pengetahuan tersembunyi dalam Revolusi Fisik di Bali. Permasalahan tersebut dikaji dengan cara mengajukan dua pertanyaan penelitian, yakni bagaimana bentuk peristiwa remeh temeh seharihari di luar arena perang gerilya selama Revolusi Fisik di Bali; serta bagaimana bentuk relasi kuasa pengetahuan di balik Revolusi Fisik di Bali.

Jawaban atas pertanyaan tersebut ditelusuri dalam informasi yang terkandung pada biografi karya Nyoman Wijaya, yang tokoh-tokohnya lahir pada 1930-an. Mereka adalah I Gusti Ngurah Bagus asal Desa Peguyangan (lahir pada 1931), Ida Pedanda Gede Dwija Ngenjung (Ida Bagus Tjetana Putra, lahir di Sanur 1934), Bhante Thita Ketoko Thera (lahir di Banjar Gulingan Tengah, Mengwi tahun 1945), Anak Agung Made Djelantik (lahir di Karangasem pada 1919). Dari biografi mereka diharapkan dua pertanyaan penelitian itu dapat dijawab dan mampu mencapai tujuan penelitian ini.

Adapun tujuan penelitian ini bukan hanya untuk melengkapi studi-studi terdahulu seperti yang sudah disebutkan. Karya mereka cenderung menyoroti masa revolusi secara makro. Studi mereka juga cenderung terpecah-pecah, lebih condong membicarakan babak ketiga (masa Revolusi Fisik-Militer), sehingga diperlukan upaya untuk menyatukannya melalui sebuah tema sentral, yakni peristiwa kecil sehari-hari yang menyatu dengan perang dan kemerdekaan dalam Revolusi Indonesia (1945-1949) di Bali.

\section{Metode}

Demi mudahnya menangkap dan memahami 'wujud' peristiwa remeh temeh sehari-hari, maka dalam hal ini, revolusi diposisikan sebagai sebuah wacana ala Foucault, sehingga bisa diasumsikan menjadi begitu banyak orang yang menangkap pengetahuan tersembunyi di baliknya untuk dijadikan sebagai kekuasaan atau strategi yang difungsikan sebagai teknik, taktik, dan manuver untuk mendisiplinkan tubuh-tubuh pihak lain. Hal itu dilakukan dengan cara menangkap pengetahuan yang tersembunyi dalam wacana primer (kemerdekaan Indonesia) untuk dijadikan sebagai kekuasaan dengan cara menciptakan wacana sekunder yang dianggap sebagai suatu kebenaran untuk mendisiplinkan tubuh-tubuh lain supaya patuh dan berguna pada kebenaran tersebut, baik yang bersifat produktif maupun nonproduktif. Jadi jelasnya, kekuasaan itu tidak ada dasarnya, karena dia bertahan sebagai jaringan kompleks yang tidak terbatas oleh kekuasaan mikro, dari hubungan yang meresap pada setiap aspek kehidupan sosial. Kekuasaan tidak hanya menindas, tetapi juga mencipta (Foucault, 1980: 114). Jadi, kekuasaan bukan sekedar sesuatu yang memaksa, menyensor, memeras, menutupi, dan menyembunyikan, tetapi juga menyangkut segala sesuatu yang bersifat produktif, menghasilkan realitas, menghasilkan domain objek dan ritual kemerdekaan (Philpott, 2003 : 22).

Teori tersebut ditopang oleh perpaduan metode Arkeologi Ilmu Pengetahuan dan metode Genealogi Kekuasaan dari Michel Foucault (Ritzer, 2014: 574-575; Rabinow, 2002: 17; Ankersmit, 1987: 310-312). Dari Arkeologi Ilmu Pengetahuan dibahas tentang aturan-aturan formasi diskursus (wacana). Sementara itu, dari genealogi kekuasaan dibahas bukan hanya kelangkaan pernyataan (statement) tetapi juga kekuasaan dari pihak yang afirmatif (menyetujui) adanya peristiwa kecil sehari-hari di masa revolusi.

Dengan kata lain, Arkeologi Ilmu Pengetahuan diperlukan untuk melaksanakan tugas Genealogi Kekuasaan. Secara spesifik, Arkeologi Ilmu Pengetahuan melibatkan analisis empiris terhadap wacana sejarah, sedangkan genealogi kekuasaan menjalankan serangkaian analisis kritis terhadap wacana sejarah dan hubungannya dengan isu-isu yang menjadi perhatian di masa prarevolusi, masa revolusi, dan pascarevolusi. Oleh karena itu, dapat diperoleh ilmu tentang cara-cara mengetahui mengapa peristiwa kecil sehari-hari di tiga desa tersebut pada masa revolusi dapat dijadikan sebagai pintu masuk untuk menjelaskan kejadian sejarah sebelum dan sesudah revolusi. Hal ini sekaligus dapat mengetahui implikasi peristiwa kecil sehari-hari pada masa revolusi terhadap peristiwa lain di masa awal kemerdekaan, khususnya yang terkait dengan perseteruan antara golongan Sosialis dengan Nasionalis di Bali. 


\section{Menyerbu Tangsi-Tangsi di Jepang}

Proklamasi Kemerdekaan RI dibacakan oleh Soekarno-Hatta atas nama bangsa Indonesia, pada 17 Agustus 1945, tepat pukul 10 pagi, bertempat di Gedung Pegangsaan Timur 56 Jakarta. Melalui radio, Proklamasi Kemerdekaan Indonesia itu menggema ke seluruh dunia. Pada 21 Agustus 1945, Pemerintah Pendudukan Balatentara Jepang yang dipimpin oleh Cookan, kepala pemerintahan tertinggi di Sunda Kecil, mengumumkan berita penyerahan Jepang kepada Sekutu dan berita proklamasi di Jakarta.

Di Desa Sanur, berita radio itu tersebar dari mulut ke mulut. Relatif sedikit orang yang memiliki radio di zaman itu, salah satunya seorang pemuda kasta brahmana, mantan anggota Seinendan, yang memiliki hubungan saudara dengan Tjetana Putra. Banyak pemuda dan orang setengah baya berkumpul di rumahnya untuk mendengarkan berita melalui siaran radio. Anak-anak kecil seusia Tjetana Putra (11 tahun) boleh ikut mendengarkannya, meskipun belum paham dengan persoalan politik.

Dua hari kemudian (19 Agustus 1945), pejabat yang diberikan kekuasaan memerintah di Sunda Kecil, I Gusti Ketut Pudja tiba di Bali. Ia diberikan jabatan sebagai Gubernur Sunda Kecil, yang wilayahnya meliputi Bali, Nusa Tenggara Barat, dan Nusa Tenggara Timur. Selain kepada Pudja, Presiden Soekarno juga memberikan jabatan kepada Ida Bagus Putra Manuaba sebagai Ketua Komite Nasional Indonesia (KNI) untuk Sunda Kecil. Sekalipun demikian secara de facto, pemerintahan Jepang masih bercokol di Bali.

Sampai kemudian pada 1 November 1945 para pemuda di bawah pimpinan I Gusti Ngurah Rai asal Puri Carangsari dan Gusti Ngurah Wisnu mengadakan pertemuan di Puri Satria, Denpasar, yang merupakan rumah dinas regent Badung. Pada pertemuan ini diputuskan pengubahan Badan Keamanan Rakyat (BKR) menjadi Tentara Keamanan Rakyat (TKR) dengan komando sentral di bawah pimpinan I Gusti Ngurah Rai berpangkat Letnan Kolonel, Komandan Resimen Sunda Kecil. Ia dibantu oleh sejumlah staf, antara lain Mayor Wisnu dan Mayor Debes. Pada 8 Desember 1945, pimpinan TKR bersama dengan PRI, PESINDO, dan kesatuan-kesatuan pemuda lainnya mengadakan pertemuan istimewa di Singaraja. Tujuan pertemuan ini untuk memersatukan tekad dan sikap terakhir terhadap tentara Jepang di Bali. Pada 11 Desember pertemuan serupa terjadi di Denpasar di bawah pimpinan I Gusti Ngurah Rai dan I Made Widjakusuma. Dalam pertemuan ini mereka mematangkan rencana pe-nyerbuan ke tangsitangsi Jepang pada 13 Desember 1945.

Dalam biografi Ide Pedanda Dwija Ngenjung (Nyoman Wijaya, 2014) disebutkan para pemuda betul-betul melaksanakan aksinya menyerbu tangsi-tangsi Jepang. Demikian pula halnya dengan para pemuda di Desa Sanur. Tjetana Putra tidak terlibat dalam rencana penyerangan tangsi Jepang, namun ia dapat menyaksikan aksi para pemuda tersebut. Suatu hari dalam sebuah perundingan di rumah salah seorang kakaknya, ia mendengarkan rencana para pemuda menyerbu tangsi Jepang. Di Desa Sanur ada sebuah tangsi Jepang, yang terletak di Kantor Pekerjaan Umum (PU) dekat Hotel Werdapura dan Hotel Tanjungsari sekarang. Pada masing-masing tangsi terdapat dua meriam berukuran besar. Sejumlah anak muda, antara lain Ida Bagus Alit Sudarma, Ida Bagus Raca, Ida Bagus Okanatha, dan Ida Bagus Banjar berkumpul di Griya Jero Gede Sanur. Mereka sedang merundingkan rencana perebutan senjata Jepang yang tersimpan di tangsi Werdapura dan Tanjung Sari.

Pada hari yang sudah ditentukan, sebelum 13 Desember 1945 para pemuda, terutama anggota Seinendan Desa Sanur berkumpul di sepanjang jalan depan Griya Jero Gede Sanur untuk melaksanakan rencana penyerbuan tangsi Jepang. Para pemuda dari Kesiman, Renon, dan Tanjung Bungkak juga ikut berkumpul di Sanur membawa senjata tajam dan bambu runcing. Upacara memohon keselamatan diselenggarakan di merajan, kuil keluarga Griya Jero Gede. Semua pusaka suci, berupa keris dan tombak diturunkan dari tempat persemayamannya untuk diberikan upacara, sebagai tanda permohonan berkah Sanghyang Widhi, Tuhan. Setelah diupacarai, keris dan tombak itu dibagi-bagikan kepada pimpinan pemuda. Tjetana Putra ikut-ikutan membawa senjata berupa pisau pendek yang disembunyikan di pinggangnya. Ia membayangkan pisau itu akan banyak manfaatnya jika betul-betul terjadi pe- 
perangan. Itu tandanya, biarpun masih di bawah umur, pada dirinya sudah muncul keberanian untuk melakukan perlawanan.

Pada 13 Desember 1945 malam, para pemuda menebangi pohon-pohon besar di Desa Sanur, lalu menggeletakkannya secara melintang di berbagai jalan utama, supaya dapat menghambat laju kendaraan tentara Jepang. Semakin malam jumlah orang semakin banyak. Banyak di antaranya yang tidak mengerti, mengapa orang-orang ramai berkumpul di depan Griya Jero Gede Sanur. Sesudah itu, terdengar suara dentuman yang sangat keras. Rupanya di antara para pemuda itu ada yang iseng-iseng membenturkan dua drum minyak tanah kosong, sehingga menimbulkan suara menggelegar bagaikan ledakan meriam Jepang. Tanpa diberikan aba-aba para pemuda lari menjauh dari tempat semula, karena menyangka tentara Jepang sudah mengepung dan membombardir rakyat dengan tembakantembakan. Jalan di depan Griya Jero Gede Sanur yang sebelumnya penuh sesak dengan jumlah orang mencapai ribuan, akhirnya sepi.

Keesokan harinya, pagi-pagi sekali pagar di depan Griya Jero Gde Sanur yang terbuat dari batang-batang bambu rusak berat, roboh seperti terinjak-injak dan senjata-senjata seperti pisau, sang-kur, dan bambu runcing bergeletakan di sepanjang jalan. Rupanya suara benturan drum itu langsung menyiutkan hati mereka. Sontak mereka membuang senjata yang tergenggam di tangan dan lari tunggang-langgang mengutamakan keselamatan diri sendiri. Menurut laporan tiga orang pimpinan pemuda, Ida Bagus Raca, Ida Bagus Alit Sudarma, dan Ida Bagus Banjar, sebelum ada dentuman suara drum, tentara Jepang sudah mundur dari tangsi masing-masing. Mereka melarikan diri ke arah selatan ke Penyaringan, berbelok ke barat, ke Desa Renon.

Fakta tersebut menunjukkan ada para pemuda belia ikut bergabung dalam aksi massa untuk menyerbu tangsi militer. Rupanya ini bukan suatu hal yang dipaksakan atau diperintahkan seperti yang berlangsung saat Perang Badung (1906) seperti sudah disebutkan di atas, melainkan hasil kompromi dengan pengalaman yang diperoleh di sekolah. Dalam biografi Ida Pedanda Dwija Ngenjung (Wijaya, 2014) disebutkan, pada April 1942 pemerintah militer Jepang membuka kembali sekolah-sekolah yang sebelumnya ditutup.
Mereka memerkenalkan model Sekolah Rakyat (SR) untuk pendidikan di tingkat dasar yang berlangsung selama enam tahun. Sebelumnya di zaman kolonial Belanda pendidikan sekolah dasar berlangsung selama lima tahun, tiga tahun di dessaschool dan dua tahun lagi di volkschool. Jepang menyeragamkan seluruh tahun ajaran sekolah dasar. Suatu hal yang baru pertama kali terjadi di Indonesia semenjak Indonesia dijajah oleh Belanda. Adanya keseragaman dalam waktu pendidikan, memudahkan penyelenggaraan, pengawasan sekolah, dan kurikulum dapat dibuat dengan lebih baik dan seragam. Dengan demikian, dalam teorinya pengetahuan murid Sekolah Dasar pada waktu Jepang itu sama di mana pun sekolah itu diadakan.

Unsur kemiliteran sangat menonjol dalam sistem pendidikan kolonial Jepang. Para guru begitu disiplin dalam proses belajar dan mengajar. Kalau ada anak yang terlambat datang ke sekolah atau tidak mampu menjawab pertanyaan yang diberikan oleh guru, sudah pasti akan mendapat hukuman pukulan bambu penunjuk papan tulis persis di bagian pantat. Semakin dekat hari-hari kekalahan Jepang dalam Perang Pasifik, semakin kacau sistem belajar mengajar di sekolah. Anakanak sekolah tidak memeroleh pelajaran sebagaimana mestinya, melainkan disuruh bekerja bakti atau gotong royong mengerjakan kepentingan Jepang. Mereka bahkan disuruh mencari ulat. Ada kalanya mereka menanam ubi atau jagung.

Siapa pun yang melakukan kesalahan akan mendapat hukuman, tidak terkecuali guru-guru. Polisi Jepang tidak sungkan-sungkan memarahi guru-guru yang dinilainya bersalah, langsung di depan para murid. Ia dan kawan-kawan sekolahnya tidak mengetahui telah terjadi arus balik dalam Perang Pasifik. Tentara Jepang yang sebelumnya memakai strategi menyerang tiba-tiba hanya mampu untuk menghindari kekalahan dari Tentara Sekutu. Jepang bahkan tampak kewalahan menghadapi gempuran Tentara Sekutu yang merupakan persekutuan antara Amerika, Inggris, Cina, dan Belanda. Menyadari tentaranya sudah terdesak, pemerintah militer Jepang berusaha menarik simpati dan dukungan rakyat. Jepang sangat membutuhkan dukungan rakyat, baik berupa bantuan material maupun moral, dan bahkan nyawa. 
Pendidikan di sekolah yang ikut membentuk keberanian pemuda usia belia terlibat dalam Revolusi Fisik di zaman Jepang terungkap dalam Biografi I Gusti Ngurah Bagus. Anak-anak Sekolah Rakyat mulai dari kelas empat hingga lima diajarkan teknik-teknik berperang. Mereka diadu antarkelas, masing-masing diposisikan seolah-olah sedang melawan musuh. Seperti misalnya, anakanak kelas empat diadu melawan anak-anak kelas lima. Mereka diwajibkan membawa beberapa peralatan perang-perangan, antara lain sumpitan, tombak, dan senapan yang semua terbuat dari bambu. Sebagai amunisinya, digunakan buah lempeni (Ardisia elliptica) dan kampuak (bunga jambu).

Strategi diatur oleh seorang komandan, yang dipilih bukan berdasar kecerdasannya, melainkan keperkasaan, ketangkasan, dan ukuran tubuhnya. Komandan kelas empat menentukan dan membagi teman-temannya ke dalam beberapa regu dengan tugas masing-masing seperti menyerang atau menjaga markas pertahanan, yang disebut tangsi. Latihan ini dilakukan di areal terbuka, di persawahan dekat sekolah. Pihak lawan, kelas lima diposisikan sebagai pasukan Jepang, diberikan sebidang tanah, tempat mereka membuat tangsi. Ia menempatkan sejumlah kawannya sebagai penjaga tangsi. Penjagaan dilakukan dengan dua cara, yakni berdiri seolaholah sedang berada di depan gardu penjagaan dan mondar mandir bagaikan sedang berpatroli mengawasi keadaan benteng. Sementara itu, anakanak kelas empat berperan sebagai sekutu, diwajibkan berjuang sekuat mungkin untuk masuk, menerobos, dan merebut tangsi.

Apabila berhasil, mereka adalah pemenangnya. Satu-satunya cara untuk memeroleh kemenangan adalah menyuruh sebagian pasukan menjebak musuh agar mereka terpancing ke luar tangsi, lalu ditembak dari belakang. Caranya, bidik senjata bedil-bedilan (senapan bambu) yang telah diisi buah lempeni sasarkan pada tubuh lawan. Jika tepat sasaran berarti yang bersangkutan harus menjatuhkan diri sebagaimana layaknya orang tertembak peluru. Mereka yang tertembak tidak boleh bangun, sebelum permainan dinyatakan berakhir. Kalau sampai tertembak, rasanya lumayan sakit, tetapi tidak ada yang sampai menangis kesakitan. Mereka malu jika mendapat ejekan belengih atau cengeng dari kawan-kawannya.

Para pemuda usia belia di Desa Sanur terbukti belum dapat mempraktikkan latihanlatihan militer yang dipelajari di sekolah, karena serangan terhadap tangsi militer Jepang gagal. Kegagalan tidak hanya terjadi di Sanur, melainkan di seluruh Bali. Kegagalan penyerbuan tangsitangsi Jepang itu mengubah jalan sejarah Bali. Tentara Jepang ke luar dari tangsi masing-masing untuk memburu para pemuda pejuang. Mereka sempat berkumpul di Puri Kesiman. Mereka tidak menyadari dirinya sudah dikepung oleh pasukan Jepang. Biarpun sudah terkepung, namun mereka berhasil meloloskan diri. Begitu para gerilyawan yang sebelumnya sudah terjepit di Puri Kesiman, Puri Satria, dan beberapa tempat lainnya di Denpasar bisa meloloskan diri, mereka langsung menuju ke Peguyangan atau desa-desa lain yang diperkirakan lebih aman.

Di Sanur, seperti terungkap dalam biografi Ide Pedanda Dwija Ngenjung, saat itu juga banyak beredar kabar bahwa Jepang telah membuang semua persenjataan dan amunisinya ke tengah laut. Tujuannya agar senjata-senjata itu tidak dirampas oleh pemuda pejuang untuk balik menyerang mereka. Tindakan Jepang itu diketahui oleh warga karena ada seorang nelayan yang dicelakai oleh peluru-peluru buangan di tengah laut. Bagaimana hal itu bisa terjadi? Kisahnya bermula saat kakek bernama Mangku Dunia menemukan granat tangan di tengah laut saat ia sedang memancing ikan. Ia yang tidak tahu apa-apa tertarik melihat bentuk granat tangan itu untuk digunakan sebagai gagang pisau. Saat ia memungut benda itu sontak terjadi ledakan yang mengakibatkan tangannya putus. Setelah kejadian ini, yakinlah para pemuda pejuang bahwa memang benar Jepang telah membuang seluruh senjata dan amunisinya ke tengah laut. Tidak ada yang tahu pasti apakah para pemuda pejuang berhasil atau tidak. Jelasnya, pemimpin perjuangan memerintahkan anak buahnya mundur ke luar kota. Mereka pun menyingkir hingga ke hutan-hutan dan pegunungan. Di tempat persembunyian, para pimpinan TKR mulai memikirkan landasan, strategi, dan siasat perjuangan. Sejak itu para gerilyawan mulai masuk ke desa-desa yang jauh dari kota, agar bisa bertemu dengan rakyat untuk 
menyosialisasikan arti kemerdekaan dan mencari dukungan dalam membangun gerakan massa yang lebih solid.

Di Buleleng, kegagalan penyerbuan tangsi militer Jepang di Banyumala, Singaraja terungkap dalam biografi Bhante Thitaketuko Thera (Wijaya, 2003). Penyerbuan tersebut ternyata gagal, karena Jepang sudah mengetahui perencanaannya, sehingga betul-betul sudah memersiapkan diri semaksimal mungkin. Jepang kemudian melakukan balas dendam. Pagi-pagi sekali pada 14 Desember tentaranya yang berada di Banyumala ke luar untuk mengejar para pemuda pejuang: PRI, Pesindo, dan TKR. Terjadilah tembak-menembak di Kota Singaraja dalam beberapa jam. Hal yang serupa terjadi pula di kota lain, yaituTabanan, dan Negara.

Melihat keadaan itu, para pimpinan mengintruksikan para pemuda yang tidak punya senjata api untuk mundur dari kota, menyingkir ke pedalaman. Malam hari saat peristiwa tersebut berlangsung, para murid masih berada di Kota Singaraja. Akan tetapi, Tangkas bersama temantemannya yakni Rugeg dan Ida Bagus Bajra, dan Made Raka dari Banjar Sengguan Denpasar ke luar kota, ke arah selatan Kota Singaraja, di sekitar Danau Beratan. Pada pukul 22.00 mereka masih berada di tengah-tengah kebun jagung. Pagi hari barulah mereka pulang masing-masing dengan membawa cerita saat penyerangan berlangsung.

Rugeg, anak seorang polisi dari Banjar Tampak Gangsul, Denpasar, mengajak Tangkas mencari senjata dengan caranya sendiri. Dia tahu sebagai seorang polisi, ayahnya pasti memiliki senjata pistol, lalu muncullah rencana pulang ke Denpasar untuk meminta pistol tersebut. Berangkatlah mereka ke Denpasar berjalan kaki melalui Kubu Tambahan terus naik ke Sawan, terus berjalan melalui jalan pintas melewati hutan, yang berjarak sekitar 80 kilometer. Di tengah hutan mereka bertemu dengan Ida Bagus Indra seorang pejuang kemerdekaan. Mungkin dia heran melihat dua orang pelajar berjalan di tengah hutan, lalu dia bertanya. Tangkas menjelaskan bahwa mereka akan ke Denpasar.

Sekalipun Tangkas sudah mengenalinya, namun Indra tampak curiga. Namun karena sedang menyamar, maka ia tidak banyak bertanya. Penyamarannya dilakukan dengan mengubah penampilannya. Ia membawa seekor ayam, berpenampilan bagai seorang petani dari desa hendak menyabung ayam ke kota. Indra melanjutkan perjalanan ke Kota Singaraja, sedangkan Tangkas dan Rugeg mencari desa terdekat, karena hari sudah menjelang malam. Mereka tiba di Desa Galungan, masih di wilayah Buleleng Timur. Kemudian menginap semalam, keesokan harinya, pagi-pagi sekali, melanjutkan perjalanan, menembus hutan-hutan terus sampai di lembah Tukad Bangka kemudian naik ke Pelaga, yang sudah termasuk wilayah Badung. Dari Pelaga ke Sangeh, Blahkiuh, menginap semalam di Abiansemal.

Setelah menempuh perjalanan dua malam, mereka mulai memasuki wilayah Kecamatan Mengwi, termasuk wilayah Badung. Tangkas mengajak kawannya mampir ke rumahnya di Banjar Gulingan Tengah, yang letaknya hanya sekitar dua kilometer di sebelah timur bekas Kerajaan Mengwi. Setelah dapat melepaskan rasa rindu terhadap keluarga, tidak lama kemudian mereka berangkat menuju Denpasar. Sesampainya di Denpasar, Rugeg mengutarakan keinginannya kepada ayahnya, tetapi dia terpaksa kecewa karena ayahnya tidak mengizinkan, karena tidak mungkin menyerahkan pistol tersebut kepada orang lain, selagi dia masih berstatus polisi aktif, lagi pula senjata ini juga sangat dibutuhkan karena dia juga merupakan salah satu pejuang di Kota Denpasar.

Peristiwa remeh temeh sehari-hari babak pertama Revolusi Fisik juga ditemukan dalam biografi I Gusti Ngurah Bagus (Wijaya, 2012) di Desa Peguyangan, enam kilometer sebelah barat Kota Denpasar. Sama halnya dengan di Sanur, pada 13 Desember 1945 para pemuda Desa Peguyangan sudah berkeinginan merebut persenjataan tentara Jepang yang bermarkas di Tangsi Baha, di Desa Mengwi, sekitar dua belas kilometer di sebelah barat laut desa ini. Mereka yang terlibat adalah pemuda yang sudah mengerti akan arti kemerdekaan. Sebagaimana diceritakan oleh Ngurah Bagus, pada sore hari sudah berkumpul sejumlah pemuda di sepanjang jalan raya Peguyangan untuk berjaga-jaga. Masing-masing membawa senjata, seperti parang, tombak, keris, bambu runcing, dan sebagainya. Lebih jauh dari itu, orang-orang yang diyakini memiliki ilmu pangeleakkan, diharapkan partisipasinya menggunakan kesaktiannya untuk membunuh tentara Jepang yang bermarkas di Tangsi Baha. 
Namun Jepang mencium rencana tersebut. Mereka segera melakukan penjagaan pada tangsitangsinya. Disadari juga oleh para pemuda pejuang bahwa kegagalan itu disebabkan oleh kurangnya strategi maupun persenjataan yang dimiliki, sehingga dengan mudah dihalau oleh tentara Jepang yang memiliki persenjataan lengkap. Atas insiden penyerbuan tangsi Jepang itu, para pemimpin pemerintah Sunda Kecil ditangkap untuk diperiksa.

Kegagalan penyerbuan tangsi-tangsi Jepang memengaruhi arah perjuangan dan sejarah Bali umumnya. Tentara Jepang yang semula sudah masuk ke tangsi masing-masing, kini berhamburan ke luar memburu para gerilyawan. Akibatnya, para pemimpin perjuangan memerintahkan anak buahnya untuk mundur ke luar Kota Denpasar. Desa Peguyangan merupakan salah satu desa pinggir kota sisi utara yang paling strategis. Desa ini begitu diminati oleh para gerilyawan memudahkan mereka menyingkir hingga ke hutan-hutan dan pegunungan. Begitu para gerilyawan yang sebelumnya sudah terjepit di Puri Satria, Puri Kesiman, dan beberapa tempat lainnya di Denpasar bisa meloloskan diri, mereka akan langsung menuju ke Peguyangan atau desa-desa lain yang diperkirakan lebih aman. Di tempat persembunyiannya, para gerilyawan akhirnya sadar, bahwa mereka bertindak terlalu gegabah, melaksanakan suatu kegiatan besar tanpa konsep yang jelas dan dasar-dasar perjuangan yang teratur dan rapi. Oleh karena itulah pimpinan TKR di bawah I Gusti Ngurah Rai mulai memikirkan landasan, strategi, dan siasat perjuangan. Sejak itu para gerilyawan mulai masuk ke desa-desa dan dusun yang jauh dari kota, agar bisa bertemu dengan rakyat, tidak saja untuk menyosialisasikan arti kemerdekaan, tetapi juga mencari dukungan untuk membangun gerakan massa yang lebih kuat dari sebelumnya.

Lebih jauh dari itu, para pimpinan TKR juga mengambil kesepakatan untuk mencari bantuan senjata ke Jawa. Pada Rabu, 19 Desember 1945 rombongan ekspedisi yang dipimpin oleh I Gusti Ngurah Rai berangkat ke Jawa. Sementara itu, para pemimpin yang berada di Bali, selain berusaha merebut hati rakyat, mereka juga membenahi struktur organisasi, kemudian melahirkan suatu konsep baru berupa induk perjuangan yang mengoordinasi para gerilyawan dalam menghadapi musuh. Induk perjuangan ini disebut Markas Besar (MB), yang membawahi beberapa cabang yang ada pada satu atau dua distrik, disebut staf. Cabang membawahi ranting yang tersebar di desa-desa. Cara kerjanya, cabang memperoleh informasi dan pengarahan dari $\mathrm{MB}$ yang kemudian diteruskan ke ranting, yang selanjutnya meneruskan ke anak buah masingmasing. Dalam situasi seperti itu, di Desa Peguyangan terbentuk base camp, markas perjuangan yang terletak di Taman, di seberang jalan Jro Gede Peguyangan.

Di tempat ini mereka berkumpul, istirahat, begadang, dan bahkan banyak yang menjadikannya bagaikan rumah. Tekad mereka hanya satu, bersiap-siap menyambut kedatangan musuh, seiring dengan beredarnya isu bahwa sebentar lagi tentara NICA akan mendarat di Bali. Segala sesuatu yang menyangkut urusan konsumsi ditanggung bersama, dengan cara gotong-royong. Setiap warga desa diharapkan berpartisipasi dan di antaranya ada yang menyumbangkan bahan makanan, seperti beras, singkong, jagung, bumbubumbu, ayam, babi, hingga sapi.

Para pelajar kelas enam ke bawah, dikoordinasikan oleh I Gusti Ketut Arya untuk menangkap belut dan ikan tawar. Sesuai dengan keputusan itu, para pelajar di antaranya termasuk Ngurah Bagus, sering sekali menghabiskan waktunya di malam hari untuk nyundih, mencari belut, dengan menggunakan penerangan lampu ala kadarnya atau memasang $b u b u$, alat untuk menangkap ikan yang terbuat dari bambu yang dianyam, dibentuk sedemikian rupa agar ikan dapat masuk dengan mudah, tetapi tidak dapat keluar lagi. Kalau ternyata pilihannya memasang $b u b u$, berarti pagi-pagi sekali, ia harus kembali ke tempat semula, untuk mengambil hasil jebakannya. Berapa pun jumlah yang diperoleh, akan dibawa ke Taman (markas perjuangan) untuk diserahkan kepada para gerilyawan yang menangani urusan logistik yang dikoordinasikan oleh Gusti Ayu Adi. Kegiatan ini umumnya dilakukan sesudah hari gelap, namun tidak sampai larut malam.

Dengan demikian, pada malam hari Ngurah Bagus dan kawan-kawan sebayanya yang sama-sama mencari belut adalah anak-anak revolusioner, tetapi di pagi hari hingga senja 
mereka adalah anak-anak kecil yang bebas tanpa ikatan. Pagi hari hingga menjelang tengai tepet, siang hari, mereka bermain-main sebagaimana biasa, mengikuti musim dan jenis permainan yang berlaku saat itu, seperti magala-galaan, matembing, dan sebagainya. Namun sore hari sekitar pukul tiga ke atas mereka sudah masuk dalam permainan yang lebih dewasa, perjudian. Kalau tidak di arena gocekan, sabungan ayam khusus yang menggunakan ayam belum dewasa sebagai aduan, Ngurah Bagus dan orang-orang yang seusia dengannya biasanya akan bermain-main sekaligus berjudi di arena togtog atau keles. Togtog merupakan suatu jenis perjudian yang menggunakan uang kepeng sebagai sarananya.

\section{Kedatangan NICA}

Kegentingan mulai meningkat setelah NICA datang. Mereka mendarat di Pantai Sanur, tempat yang dulu menjadi tempat kapal perang Belanda berlabuh pada saat akan menggempur Kerajaan Badung pada 1906. Semula mereka mengira para pejuang Bali akan melawan tentara NICA melalui suatu pertempuran sengit. Namun yang terjadi sebaliknya, tidak ada perlawanan. Sebagaimana dipaparkan secara cermat oleh Nyoman S. Pendit mereka begitu mudah mengambil alih kekuasaan. Pada Sabtu, 2 Maret 1946 tentara NICA yang menyebut diri sebagai "Gajah Merah" mendarat di Sanur. Mereka langsung menduduki Kota Denpasar untuk menggantikan tentara Sekutu yang sudah bercokol sejak Minggu, 18 Februari 1946. Setelah itu, secara berturut-turut NICA menaklukkan daerah lainnya. Keesokan harinya mereka sudah menduduki Kota Gianyar, dua hari berikutnya Singaraja, disusul Tabanan, Negara, dan seterusnya.

Di Singaraja, Senin, 5 Maret 1946 di hadapan para pejabat negara, Gubernur Sunda Kecil menyebut diri sebagai AMACAB/AFNEI (Allied Forces, Nederlands East Indies). Di sini terjadi perundingan antara perwakilan NICA dengan para pejabat tinggi Bali. Dalam perundingan itu NICA meminta bantuan pemerintah Indonesia untuk membantunya melaksanakan tugas membebaskan tawanan serikat, melucuti tentara Jepang, dan memulangkan mereka ke negara asal. Dalam perundingan itu, sama sekali tidak disinggung masalah politik, bahkan bendera Merah Putih dibiarkan tetap berkibar dan roda pemerintahan Republik Indonesia berjalan sebagaimana mestinya.

Enam hari kemudian, ternyata kesepakatan itu langsung dikoyak-koyak. Tentara NICA menangkap Puja (Gubernur Sunda Kecil), Ida Bagus Manuaba (Ketua KNI), dan Ketua Jawatan Pajak di tempat kediaman mereka masing-masing, lalu dibawa ke Denpasar, ditahan di salah satu kamar Bali Hotel. Dengan demikian, Revolusi Fisik di Bali telah memasuki babak kedua. Tidak semua pemuda usia belia mau dan berani berpartisipasi dalam perjuangan yang dilakukan oleh para gerilyawan. Pendidikan perang-perangan dan kedisiplinan yang diajarkan di sekolah di zaman Jepang tidak terpakai. Mereka lebih banyak tinggal di rumahnya. Dari keempat tokoh biografi yang dijadikan pintu masuk dalam studi ini hanya dua orang yang berani ikut bergabung, yakni I Gusti Ngurah Bagus dan I Ketut Tangkas.

Mengingat sekolah $\mathrm{Cu}$ Gakko sudah bubar dan situasi politik semakin memanas, maka Tangkas memandang sudah tidak ada lagi gunanya tinggal di Singaraja. Akan tetapi, ia belum bisa meninggalkan kota ini, karena di sini masih ada Nyonya Ida Bagus Putra Manuaba (yang merupakan induk semangnya) beserta dua orang anaknya, yakni Ida Bagus Adnyana dan Ida Bagus Nurcahya. Anak yang nomor satu sangat dekat dengan Tangkas, karena sering ditugaskan oleh Nyonya Manuaba untuk mengawasi dan melayani keperluannya, tugasnya mirip baby sitter.

Di sisi lain, anak-anak sekolah yang ikut menyingkir ke hutan, disuruh kembali ke tempat masing-masing, supaya tidak terjadi konsentrasi massa yang tidak jelas bentuk dan tujuannya. Hanya orang-orang serius dalam perjuangan yang disertakan. Dalam lingkungan $\mathrm{Cu}$ Gakko banyak yang dikerahkan sebagai pembuat plakat dimotori oleh Kunawinaya. Ada juga yang mendapat tugas memungut sampah di kota. Tangkas ikut di dalamnya sebagai pemungut sampah.

Setelah keluarga Manuaba dipindahkan untuk ditahan di Denpasar, barulah beberapa minggu kemudian Tangkas meninggalkan Singaraja. Ternyata ia tidak langsung ke rumahnya, melainkan menuju rumah keluarga Ida Bagus Manuaba. Susetyo dan Sujiran (dua orang kawan Tangkas) berangkat lebih awal, langsung menuju 
Kampung Tiga, di rumahnya Made Yasmin, adik ipar Ida Bagus Tantra.

Sementara itu, tentara NICA juga melakukan penangkapan-penangkapan di Kota Denpasar. Tentara Jepang yang masih berada di posnya masing-masing diperintahkan berangkat ke kota terdekat, selanjutnya digiring ke Denpasar sambil membawa dan kemudian menyerahkan semua senjata serta perlengkapan perang lainnya kepada NICA sebagai wakil "Serikat." Sambil mengamankan situasi, mereka juga melakukan provokasi, menurunkan bendera merah putih, menangkap para pemimpin, dan menyatakan NICA sebagai satu-satunya pemerintahan yang sah di Bali.

Pada 10 April 1946, para gerilyawan melakukan serangan terhadap tangsi NICA di Kayumas, Denpasar. Serangan ini dipimpin oleh Mayor Gusti Bagus Sugianyar. Salah seorang gerilyawan bernama Ida Bagus Djapa tewas dalam peristiwa itu, tertembak saat sedang berada di tembok tangsi Kayumas. Tentara NICA kemudian mengejar para gerilyawan ke Desa Peguyangan, sekitar lima kilometer di sebelah utara Denpasar. Mereka mendapat informasi para gerilyawan bersembunyi di desa ini. Pada 13 April 1946, tentara NICA mengepung Desa Peguyangan. Mereka menggiring penduduk supaya mau berkumpul di suatu tempat untuk diperiksa satu per satu. Untuk mencari barang bukti mereka menggeledah rumah-rumah penduduk. Mereka yang punya barang bukti ditangkap, dianiaya bahkan ada yang dibunuh. Sejumlah pemuda pejuang terkena tembak dan tewas dalam pengepungan itu. Sebagian besar lainnya, hanya ditangkap, digiring, lalu diinterogasi (Pendit, 2008: 22).

Melalui biografi I Gusti Ngurah Bagus (Wijaya, 2012) dapat diketahui Desa Peguyangan dikurung dan diobrak-abrik dari dalam oleh pasukan NICA. Tentara NICA mendapat informasi bahwa para gerilyawan di desa ini dan para gerilyawan yang bersembunyi di sini adalah motor penggerak dari serangan tersebut. Hal itu tidak bisa ditutup-tutupi, karena beberapa hari sebelum peristiwa tersebut, sejumlah pentolan gerilyawan dari Denpasar seperti I Gusti Ngurah Kusuma Judha (dari Puri Kesiman, Denpasar), I Gusti Ngurah Pindha (dari Jro Den Kayu,
Mengwi), Ida Bagus Djapa dan G. K Regig bersembunyi di desa ini. Di sini mereka mengatur strategi serangan bersama dengan para pimpinan pejuang lokal di antaranya I Wayan Diarsa.

Setelah itu pertempuran meluas. Para pemuda melakukan perang gerilya. yang dipimpin oleh I Gusti Ngurah Rai. Ketika NICA semakin sulit mengendalikan, pemerintah Belanda mencoba memakai taktik perundingan. Dalam biografi Anak Agung Made Djelantik (Wijaya, 2018) seorang pejabat senior Ministry of Overseas Teritories di Den Haag sampai turun tangan untuk menyelesaikan perang tersebut melalui perundingan dengan menggunakan Djelantik sebagai pintu masuknya. Djelantik adalah putra Raja Karangasem. Ia bersekolah di salah satu fakultas kedokteran di Belanda. Menikah dengan Astri, seorang gadis Belanda. Setelah lulus ia bekerja sebagai dokter di sebuah rumah sakit setempat.

Sementara di Sanur, peristiwa remeh temeh sehari-hari (narasi kecil) di zaman NICA terungkap dalam biografi Ida Bagus Tjetana Putra. Meskipun pertempuran semakin meluas, namun kehidupan di Kota Denpasar, termasuk di dalamnya Desa Sanur berjalan dengan normal. Kantor-kantor pemerintahan masih buka, demikian pula pusat-pusat perdagangan, pasar, dan warung-warung. Suatu hal yang belum bisa berjalan normal adalah dunia pendidikan. Sejak pembacaan naskah proklamasi dan kedatangan pasukan NICA, sudah hampir tujuh bulan murid-murid tidak bersekolah. Murid-murid sekolah menengah, seperti sudah disebutkan di bagian lain, sebagian terlibat dalam Revolusi Fisik. Akan tetapi, tidak demikian dengan murid-murid sekolah rakyat. Usia mereka masih terlalu muda untuk terlibat dalam peperangan. Ida Bagus Tjetana Putra misalnya, baru berusia 12 tahun. Bersama dengan anak-anak seusianya, ia memanfaatkan waktunya untuk bermain-main. Ia memiliki teman sepermainan yang jumlahnya berkisar antara 10 sampai 15 orang

Situasi dan kondisi di Bali berubah setelah Revolusi Fisik memasuki babak ketiga, yaitu kekalahan pasukan Ciungwanara di bawah pimpinan Letkol I Gusti Ngurah Rai dalam perang di lahan terbuka pada 20 November 1946. Seperti terungkap dalam biografi I Ketut Tangkas, 
keesokan harinya, Kamis 21 November 1946 NICA mengumumkan peristiwa tersebut keliling kota Denpasar menggunakan mobil dengan pengeras suara. Dengan demikian, sebagian besar anggota masyarakat dan anak-anak sekolah di lingkungan Denpasar mengetahui peristiwa kekalahan itu. Ketika itu mereka sedang di dalam kelas, kira-kira sekitar pukul 09.00 NICA berkeliling kota menyerukan bahwa telah menghancurkan seluruh pejuang Bali. Kemudian mereka semua keluar dari kelas, dan langsung mendengar berita kehancuran pejuang Bali. (Wijaya, 2003: 98).

Setelah sampai di rumah, Tangkas mendapat kabar bahwa Tantra (Pak Poleng yang merupakan kemenakan Manuaba) tidak terlibat dalam pertempuran tersebut. Di kemudian hari, ia akhirnya tahu bahwa masih banyak tokoh pejuang yang selamat. Selain Ida Bagus Tantra, ada juga I Made Widjakusuma, Ketut Widjana, Gusti Ngurah Mataram, Nengah Tamu (Tjilik), Subroto A.M., Nyoman Mantik, Nengah Pantjer, Ida Bagus Kalem, Gusti Ngurah Bonjoran. Merekalah yang kemudian melanjutkan perjuangan, di bawah pimpinan umum Widjakusuma. Konsolidasi pun segera dilakukan.

Sementara anggota DPRI Sunda Kecil yang masih tersisa itu sedang bertahan di hutan-hutan dan gunung-gunung. Pada Rabu 18 Desember 1946 NICA melangsungkan Konferensi Denpasar, yang melahirkan Negara Indonesia Timur (NIT) dengan ibu kota di Makassar dan Tjokorda Gde Raka Soekawati (asal Puri Ubud) terpilih sebagai presidennya serta Ide Anak Agung Gde Agung asal Puri Gianyar sebagai Perdana Menterinya.

Kehadiran NIT ditandai dengan munculnya tindakan agresif polisi dalam menyisir keberadaan para gerilyawan. Hal itu sesuai dengan keinginan H.J. van Mook dalam persidangan Konferensi Denpasar yang menyatakan akan membasmi para gerilyawan yang masih melakukan perjuangan dengan menggunakan alat politik dan organisasi sipil (NIT) yang segera dibentuk. Sementara itu, anggota MBI di bawah pimpinan Tantra masih aktif melakukan gerilya. Demi menyambung komunikasi dengan keluarganya, maka Ida Bagus Anom yang merupakan adik tiri Tantra menugaskan Tangkas menjadi penghubung. Tugasnya adalah membawa surat untuk Tantra yang sedang berada di tengah hutan. Saat itu
Tangkas sudah menjadi siswa Sekolah Menengah Denpasar yang dibuka oleh pemerintah NIT.

Sekalipun isi surat tersebut tidak menyangkut strategi perjuangan, melainkan hanya informasi tentang keadaan keluarga, tetapi siapa pun tidak boleh tahu tugas rahasia tersebut, karena taruhannya adalah nyawa. Sekali ketahuan, Tangkas bisa tertangkap, tidak saja akan menyangkut dirinya, tetapi juga keluarganya, di Gulingan Ida Bagus Oka dan Ida Bagus Manuaba sebagai pamannya. Tangkas sadar risiko seperti itu terbentang di hadapannya, yang bisa menjatuhkannya, jika lengah. Rupanya ia cukup bisa membawa diri, tidak pernah mau berceritra tentang sesuatu hal secara ceplas-ceplos. Ini sesuai dengan kepribadiannya yang tidak gemar mengobral kata, pendiam.

Waktu itu Tantra berada di antara Sobangan, Mengwi, sekitar dua puluh kilometer dari Denpasar. Untuk menuju ke sana ia harus berjalan kaki menyusuri sungai di malam hari, karena tidak mungkin tugas seperti itu dilakukan pada siang hari. Menjelang sore, ia mempersiapkan sepeda gayung, memastikan ada atau tidaknya angin, mengambil surat yang akan dibawa, menggulunggulungnya sampai kecil, lalu dimasukkan ke dalam lubang stang sepeda, kemudian ditutup seperti semula.

Setelah melaksanakan tugasnya, ia tidak langsung pulang ke Denpasar, tetapi menginap di Penarungan, di sebelah timur Desa Gulingan. Pada pagi hari barulah ia berangkat ke Denpasar. Ia tidak mau menginap di Gulingan, karena sudah betulbetul mengetahui kondisi politik di Mengwi. Pulang ke Denpasar harus dilakukan secara hatihati, karena NICA, baik polisi maupun tentaranya bertugas menangkap para pemuda pejuang. Siapa pun yang berani berpihak kepada tentara Republik Indonesia akan mendapat bencana. Sangat sulit bagi mereka untuk menghindar, karena di dalam tubuh NICA tidak saja ada orang-orang Belanda totok, tetapi juga orang-orang pribumi luar Bali, namun banyak juga orang-orang Bali yang oleh masyarakat disebut NICA Gandek. Oleh karena itu, orang-orang Gulingan sangat takut dengan Mengwi, sehingga semangat perjuangan mereka luntur, tidak ada lagi orang yang berani menunjukkan keberpihakan kepada para pejuang.

Selain menembak para gerilyawan, polisi dan tentara NICA juga menangkap orang-orang 
republikein. Belanda juga meningkatkan propaganda antiperjuangan rakyat. Untuk itu mereka mengedarkan beberapa selebaran yang menyebutkan bahwa militer Belanda akan memberikan hadiah kepada siapa pun yang dapat menunjukkan tempat sarang gerilyawan dan yang mampu menangkap pemimpinnya dalam keadaan hidup maupun mati. Di tengah-tengah situasi seperti inilah Ngurah Bagus saat berusia 15 tahun terlibat dalam kegiatan revolusioner yang bisa membahayakan keselamatan jiwanya. Ia terlibat dalam perjuangan sebagai penghubung, orang yang bertugas mengantarkan pesan atau surat kepada gerilyawan bernama Tjokorda Agung Tresna.

Sementara itu, aksi agresif tentara NICA di Desa Sanur terungkap dalam biografi Ide Pedanda Dwija Ngenjung (Wijaya, 2013). Mereka ingin menangkap para pemuda pejuang asal desa ini. Desa Sanur memiliki sejumlah pejuang antara lain Ida Bagus Alit Sudarma, Ida Bagus Raca, dan Ida Bagus Banjar, yang merupakan bagian dari Griya Jero Gde Sanur. Selain pemuda pejuang, Desa Sanur juga memiliki sejumlah NICA Gandek, tiga di antaranya berasal dari Banjar Panti Sanur. Setelah memperoleh informasi yang dibutuhkan, NICA Gandek (orang-orang yang pro-Belanda) akan berkoordinasi dengan polisi NIT yang tinggal di sebuah asrama polisi, Asrama Baruna sekarang. Polisi NIT dalam asrama itu berada di bawah pimpinan Ida Bagus Kondra, yang berasal dari salah satu Griya di Denpasar. Mereka sering meneror warga Sanur. Suatu saat pada hari pasaran, Ida Bagus Kondra bersama kawan-kawannya datang ke pasar di bawah pohon beringin di sebelah Griya Jero Gede Sanur. Kedatangan mereka yang berjumlah sampai 10 orang itu bukan untuk berbelanja, melainkan hanya beraksi menakutnakuti rakyat dengan cara menembak burung Jalak yang hinggap di ranting pohon beringin dengan menggunakan karaben.

Polisi dan NICA Gandek itu juga beraksi pada saat ada razia. Semua laki-laki dewasa harus keluar rumah dan berkumpul di depan rumah atau balai banjar masing-masing. Mereka ikut memeriksa kondisi fisik orang-orang yang sedang dirazia. Mereka yang berambut gondrong atau yang wajahnya pucat, diambil, ditahan, dan diinterogasi karena disinyalir sebagai gerilyawan yang membela Republik Indonesia. Suatu saat Ida
Bagus Gde, yang merupakan kakaknya Tjetana Putra ditahan karena berambut gondrong dan wajahnya pucat setelah beberapa hari sebelumnya jatuh sakit. Mengetahui anaknya ditahan, Ida Bagoes Anom Ngoerah, ayah Tjetana Putra segera pergi ke Denpasar untuk menjumpai Cokorda Pemecutan yang dikenal sebagai Cokorda Gambrong, yang merupakan Regent Badung, pengganti Tjokorde Alit Ngurah. Atas bantuannya, Ida Bagus Gde akhirnya dikeluarkan dari rumah tahanan.

Pada waktu yang hampir bersamaan, salah seorang kerabat Griya Jero Gede Sanur juga hampir ditangkap oleh Tentara NICA. Saat itu Griya Jero Gede Sanur sedang sepi, Ida Bagus Tjetana Putra sedang asyik membuat wayang dengan salah seorang saudaranya, yakni Ida Bagus Nyoman. Tiba-tiba datang tentara NICA mengadakan razia. Saat menuju dapur, tentara tersebut mendapati seorang laki-laki sedang mengupas kelapa. Laki-laki itu adalah kerabat Griya Jero Gede Sanur bernama Ida Bagus Wesi. Ia memang sedikit mengalami keterbelakangan mental, sehingga penampilannya tidak terurus. Rambutnya panjang dan kumal, serta menggunakan celana pendek persis penampilan para pemuda gerilyawan. Tentara NICA sontak mencurigainya sebagai pemuda gerilyawan yang menyamar sebagai orang biasa. Ia pun berusaha menjelaskan kalau Wesi bukanlah gerilyawan melainkan seorang kerabatnya yang memiliki keterbelakangan mental. Tentara NICA tidak begitu saja memercayai penjelasan yang disampaikan oleh Ida Bagus Tjetana Putra. Mereka malah menggelandang Wesi ke halaman rumah, menuju ke sebuah lubang yang terletak di sebelah bangunan gedong tempat penyimpanan arca.

Lubang itu dulunya merupakan tempat persembunyian yang dibuat oleh ayah Ida Bagus Tjetana Putra di zaman Jepang untuk mengantisipasi bila perang meletus. Karena tidak digunakan lagi, lubang itu penuh ditutupi sampah. Tentara NICA itu pun menyuruh Wesi untuk masuk ke dalam lubang itu. Dia menolak dengan beralasan bahwa di dalam lubang banyak ularnya. Tjetana Putra pun tertawa dalam hati mendengar ucapan Wesi yang tidak bisa dengan jelas mengucapkan ada lelipi (ular) ke dalam bahasa Bali, karena ia memang cadel. Tentara NICA itu 
pun akhirnya percaya bahwa ia bukanlah pemuda gerilyawan.

Selain sering menangkap orang sembarangan, masih ada beberapa tindakan tentara NICA Gandek yang tidak disukai warga masyarakat, yakni mereka suka mencuri. Pencurian ini biasanya terjadi saat mereka mengadakan razia terhadap pemuda-pemuda pribumi. Saat itu tentu saja rumah-rumah warga hanya dijaga oleh kaum wanita dan anak-anak, sehingga mereka bebas mengobrak-abrik rumah warga tanpa perlawanan yang berarti. Tjetana Putra memiliki kisah menarik tentang hal ini. Saat pemuda-pemuda dikumpulkan, ia hanya bisa diam menunggu di rumah. Ia memang bertugas menjaga rumah selama razia berlangsung. Ini karena kesemenamenaan tentara NICA yang sering mencuri barangbarang berharga milik warga dengan dalih untuk keamanan tentara NICA. Sudah banyak warga yang mengeluhkan hal ini, namun tidak digubris. Akan tetapi, ada berita tentara NICA merampas barang berharga milik warga.

\section{Relasi Kuasa-Pengetahuan dalam Revolusi Fisik di Bali}

Dilihat secara sepintas cerita tersebut di atas hanya terbatas pada sejarah prosesual yang menyangkut apa, siapa, kapan, dan dimana. Padahal ada struktur yang mengikatkan (Kartodirdjo, 1992: 108-117). Struktur tersebut terkait dengan kekuasaan di zaman kerajaan, yang terwakili oleh Puri Satria, Puri Kesiman, Jero Gede Peguyangan, Jero Gede Sanur, Puri Pemecutan, Puri Carangsari, Puri Ubud, Puri Gianyar, dan Puri Karangasem. Jika ditempatkan dalam landskap zaman kerajaan, mereka adalah situs-situs sejarah, yang para tuannya (rajanya) terlibat dalam perang saudara pada abad XIX. Puri Satria adalah rumah dinas regent Badung yang dijabat oleh keturunan Raja Puri Denpasar. Raja ini merupakan salah satu dari tiga raja yang bersama-sama memerintah di Kerajaan Badung. Dua raja lainnya bertahta di Puri Kesiman dan Puri Pemecutan. Sementara itu, Jero Gede Peguyangan dan Jero Gede Sanur merupakan dua dari sekian banyak rumah pejabat bawahan Kerajaan Badung yang selalu siap membela tuannya apabila terjadi perang antarkerajaan.
Namun struktur kekuasaan di zaman kerajaan itu bukan merupakan faktor utama yang menjadi penentu keterlibatan seseorang dalam Revolusi Fisik di Bali, bahkan boleh dikatakan sudah tidak ada pengaruhnya lagi. Kejadiannya justru berbanding terbalik. Di zaman kerajaan Puri Carangsari adalah bawahan Kerajaan Mengwi. Pada 1891, Badung yang semula hanya negeri bawahan berhasil mengalahkan Mengwi. Penguasa Puri Carangsari sampai meminta suaka politik kepada Punggawa Ubud yang merupakan bawahan Kerajaan Gianyar agar tidak diserang oleh Kerajaan Badung yang berkoalisi dengan Tabanan (Nordholt, 1996). Di zaman Revolusi Fisik justru anggota keluarga Puri Carangsari yang terpilih menjadi komando Tentara Keamanan Rakyat (TKR) yang sebelumnya bernama Badan Keamanan Rakyat (BKR), sedangkan keturunan raja-raja lainnya ada yang menjadi bawahan.

Bukan hanya itu, patahan, retakan, bahkan keterputusan fakta sejarah juga terjadi di Gianyar. Di zaman kerajaan seperti sudah disebutkan di atas, kedudukan Puri Ubud lebih rendah daripada Puri Gianyar. Namun di zaman revolusi menjadi berbalik yang terpilih menjadi Presiden NIT adalah Tjokorda Gede Raka Soekawati, seorang keturunan Punggawa Ubud, sedangkan Ide Anak Agung Gde Agung, yang merupakan keturunan Raja Gianyar menjadi bawahan. Mereka punya hubungan darah. Ida Anak Agung Gde Agung adalah kemenakan sekaligus menantu Tjokorda Gede Raka Soekawati. Ibunya adalah kakak kandung Tjokorda Gede Raka Soekawati, sedangkan istrinya merupakan anak kandungnya (Agung, 1993: 206).

Tali persaudaraan yang sudah terbentuk di zaman kerajaan itu terabaikan begitu saja dalam Revolusi Fisik. Hal itu terlihat di Gianyar. Ketika perang gerilya sedang berlangsung di gununggunung, ternyata PPN bentukan Raja Gianyar begitu aktif menangkap orang-orang yang diduga terlibat atau pro-Republik. Mereka yang berhasil ditangkap, lalu ditahan dan disiksa dalam penjara. Ternyata tidak semua tawanan itu pemuda pejuang, melainkan banyak juga orang yang tidak terlibat dalam Revolusi Fisik di Bali, seperti yang dialami oleh Tjokorde Gede Agung Soekawati, adik tiri Tjokorde Gde Raka Soekawati, Presiden NIT. Pada awalnya, ketika masih di zaman Jepang, dia bersama dengan sejumlah anggota keluarganya, 
mengungsi dari Puri Ubud sambil membawa barang perhiasan dan senjata pusaka warisan leluhurnya yang ingin 'dirampas' oleh tentara Jepang. Pengungsian itu berlanjut hingga masa NICA, dia akhirnya ditangkap, ditahan, dan disiksa lebih dari satu bulan.

Perselisihan juga terjadi dalam anggota keluarga Kerajaan Badung, terutama terkait dalam soal keterlibatan atau keberpihakan mereka terhadap NICA. Ada yang melawan dan ada pula yang berkompromi. Puri Satria termasuk pihak yang melawan. Tjokorda Agung Tresna, salah seorang anggota keluarga Puri Satria bernama terlibat aktif dalam Revolusi Fisik. Ia adalah salah seorang putra Tjokorda Alit Ngurah (I Gusti Alit Ngurah), Regent, wali pemerintahan Hindia Belanda di Badung. Jabatan ini sudah dipegangnya sejak 1929. Ketika itu Residen J.J. Caron mengeluarkan surat keputusan tentang pengangkatan para keturunan raja di Bali sebagai Negara Bestuuder. I Gusti Ngurah Made Kesiman di Puri Kesiman sudah berumur 22 tahun. Akan tetapi, Caron memberikan jabatan itu kepada I Gusti Alit Ngurah.

Semula Tresna seorang laki-laki biasa yang membuka usaha swasta di Surabaya. Dia masih berada di kota ini, pada saat berlangsungnya pertempuran 10 November 1945 di Surabaya, di bawah pimpinan Bung Tomo. Mengetahui hal itu, ayahnya, Tjokorda Alit Ngurah segera meminta bantuan kepada I Gusti Ngurah Rai, agar menugaskan salah seorang anak buahnya untuk mencari Tjokorda Agung Tresna dan mengajaknya pulang ke Bali. Setiba di Bali, ia langsung bergabung dengan MBO DPRI Sunda Kecil. Dia tidak berani langsung menghadap ayahnya Tjokorda Alit Ngurah di Puri Satria, melainkan bergabung dengan MBO DPRI Sunda Kecil, dan menghabiskan waktunya untuk mengomunikasikan perjuangan dengan para gerilyawan di berbagai tempat (I Gusti Ngurah Rai Mirsha, et al., nd,: 189).

I Gusti Alit Ngurah memilih melepaskan jabatannya sebagai Regent Badung, supaya bisa sepenuhnya membela Republik Indonesia. Sementara raja-raja lainnya di Bali sebagian besar memilih berkompromi dengan NICA. I Gusti Alit Ngurah menugaskan seorang anaknya, Tjokorde Bagus Sayoga bertemu dengan Presiden Soekarno di Yogyakarta untuk menyampaikan surat pernyataan bahwa Puri Satria berpihak pada Republik Indonesia. Sayoga menjalankan tugas itu bersama Mahadewa, salah seorang temannya di Brigade 16, seorang polisi asal Singaraja. Mereka tidak bisa langsung bertemu dengan Soekarno, karena ada rapat-rapat di istana. Barulah setelah selesai rapat mereka bisa bertemu. Setelah cerita basa-basi mengenai seni tari di Bali, Presiden Soekarno sempat menanyakan situasi perjuangan di Bali dan apa yang akan dikerjakan oleh Sayoga nanti setelah tiba di Bali (Wawancara Nyoman Wijaya dan Nyoman Sukiada dalam ARC Project 1996).

Dalam peristiwa tersebut di atas, perbedaan pilihan politik antara Puri Satria dan Puri Pemecutan, bukan saja dapat dipakai sebagai pintu masuk untuk memahami peristiwa politik di Bali pada 1940-an, tetapi juga di zaman kolonial. Di awal 1950-an yang ditandai dengan terjadinya perseteruan antara Partai Sosialis Indonesia (PSI) dan Partai Nasional Indonesia (PNI) Puri Kesiman dan Pemecutan pro-PNI, sedangkan Puri Pemecutan ke PSI (Dwipayana, 2004: 86). Orang Bali menyebut fenomena ini matungkas, asal berbeda, dan ini berlaku hingga sekarang, saat pemelihan Gubernur Bali yang baru lalu.

Perbedaan itu tidak semata-mata karena alasan ideologi politik yang satu lebih baik daripada yang lain, namun ada latar belakang sejarahnya, sehingga bisa dijadikan sebagai pintu masuk untuk menjelaskan peristiwa Perang Badung versus Belanda 1906, yang lebih dikenal dengan sebutan Perang Puputan Badung. Di balik peristiwa tersebut, ada masalah cinta segitiga yang melibatkan pangeran dari Puri Denpasar, pelaku utama dalam Perang Puputan Badung (yang anak cucunya kemudian tinggal di Puri Satria) dengan pangeran Puri Pemecutan, suatu hal yang belum terungkap dalam sejarah 'resmi'. Sejak peristiwa itu bangsawan di kedua bekas istana Kerajaan Badung itu, menerapkan politik asal berbeda (Hasil wawancara dengan I Gusti Ngurah Made Pemecutan, pelukis Sidik Jari, di Denpasar pada 14 Februari 2017). Di zaman kolonial, jika yang satu pro-Belanda, yang satu lagi memilih tidak bergabung dan cenderung gerakan nasionalis dan ini berlangsung hingga zaman Revolusi Indonesia (1945-1949), jika yang satu pro-Republik dan yang 
satu lagi pro-NICA (Wawancara Nyoman Wijaya dan Nyoman Sukiada dengan Ida Bagus Tantra dalam ARC Project, 1996).

Jadi pada dasarnya, keterlibatan orangorang dalam Revolusi Fisik di Bali merupakan hasil kompromi mereka dengan pengetahuan yang tersembunyi dalam wacana kemerdekaan termasuk pada pemuda belia usia 11-15 tahun itu. Setiap orang menangkap pengetahuan yang tersembunyi dalam wacana tersebut sesuai dengan tingkat pengetahuannya masing-masing dengan menciptakan wacana sekunder yang dianggap sebagai suatu kebenaran dengan tujuan untuk menghasilkan tubuh-tubuh yang patuh dan berguna, baik secara produktif atau nonproduktif. Wacana sekunder itu dilontarkan oleh orang-orang yang punya kuasa berbicara (orang-orang terdekat) dan setiap orang berkompromi dengannya. Hal itu terlihat pada orang-orang usia belia dalam empat biografi ini. Sekalipun mereka sama-sama mendapatkan pelajaran kemiliteran dan kedisiplinan di sekolahsekolah zaman Jepang, namun tidak semua berani terlibat secara langsung dalam revolusi. Hanya dua orang dari mereka yang mempunyai kesempatan menjadi penghubung, loper surat untuk para pemuda pejuang. Mereka adalah I Gusti Ngurah Bagus dan I Ketut Tangkas.

Keterlibatan Ngurah Bagus sebagai penghubung tidak lepas dari peran I Gusti Ketut Gede, yang masih ada hubungan keluarga dengannya di Jero Tengah Peguyangan. Ia merupakan salah seorang bawahan Tjokorda Agung Tresna di Desa Peguyangan. Tresna bergabung dalam MBI, sebagai kepala Markas Badung. Oleh karena itu, dia bersembunyi dan bergerilya di hutan Antakan, tidak sekalipun berani muncul di kota. Akhirnya, dia tidak bisa lagi bertemu dengan kekasihnya, Gusti Ayu Putra, juga dari Puri Satria, yang tiada lain merupakan kakak kelas Ngurah Bagus. Demi dapat menjalin komunikasi dengan kekasihnya, Tresna lalu meminta tolong mencarikan seorang pemuda belia mengantarkan surat-suratnya. Gusti Ketut Gede, kemudian meminta tolong kepada Ngurah Bagus untuk melaksanakan tugas tersebut. Jadi Ngurah Bagus bersedia menjalankan tugasnya sebagai penghubung karena ia berkompromi dengan I Gusti Ketut Gede, orang yang punya kuasa berbicara dalam soal perjuangan kemerdekaan di Desa Peguyangan.
Demikian pula Tangkas, yang sekalipun tidak lagi termasuk pemuda usia belia, namun informasinya mampu memerkaya fakta mengenai peristiwa remeh-temeh sehar-hari di zaman Revolusi Fisik. Kesediaan tangkas menjadi penghubung surat-surat untuk Tantra karena ia berkompromi dengan induk semangnya, Manuaba. Perkenalan Tangkas dengan Manuaba terjadi secara kebetulan ketika ia bersekolah di $\mathrm{Cu}$ Gakko di Singaraja. Informasi mengenai Manuaba diperoleh dari Ida Bagus Wisnem, tempatnya menginap ketika pertama kali bersekolah di Pertiwi Putra School (PPS) Tabanan selama setahun. Atas informasi itulah ia memutuskan indekos di rumah Manuaba. Di rumah ini ia bertemu dengan Ida Bagus Tantra. Ia tidur satu kamar dengan Ida Bagus Tantra, namun beda tempat tidur. Di rumah ini ada juga Ida Bagus Wisnu, kakak kelasnya di $\mathrm{Cu}$ Gakko, yang saat itu baru kelas dua.

Setelah Tantra pindah ke Denpasar, Tangkas satu kamar dengan Wisnu. Setelah itu datang penghuni baru, dua orang dari Jawa, Sujiran dan Susityo. Datang pula satu orang dari Bali namanya I Made Jaya. Kedua orang tersebut ternyata pemuda pejuang yang dikirim dari Jawa. Mereka mengambil sekolah guru, tetapi belum tamat, karena harus ikut bertempur melawan musuh. Sekalipun tinggal dengan pemuda pejuang, tetapi Tangkas belum memikirkan masalah politik, namun pelan-pelan Manuaba menggemblengnya, secara langsung maupun tidak langsung. Ida Bagus Manuaba merasa berkepentingan memberikan pendidikan politik kepada setiap pemuda, termasuk keponakannya sendiri Tantra.

Tinggal di lingkungan para pejuang, akhirnya memengaruhi jalan hidupnya, apalagi Pak Tasik salah seorang guru yang dikaguminya yang paling berani memberikan informasi tentang situasi politik di Jawa termasuk anak didik Manuaba di bidang politik. Semula ia memang tidak mengerti jalan pikiran para pemuda seperti Pak Tasik, sehingga dalam tata pergaulan di rumah tersebut, ia hanya sampai pada tingkat melayani teman-teman yang lebih dewasa, tidak lebih dari itu. Akhirnya, jalan pikirannya berubah, "Saya tertarik suasana berjuang, kita dilatih untuk itu." Orang tuanya di rumah tentu tidak mengetahui jalan hidup yang dipilih anaknya.

Jadi, kesediaan Tangkas menjadi penghubung surat Tantra karena ia berkompromi 
dengan wacana perjuangan kemerdekaan yang berkembang di lingkungan tempat tinggal dan sekolahnya. Situasinya berbeda dari lingkungan tempat tinggal Tjetana Putra dan Djelantik. Mereka juga berbeda umur. Djelantik sudah berusia 27 tahun di masa Revolusi Fisik, sebaya dengan I Gusti Ngurah Rai (pemimpin TKR) dan berada di negeri Belanda ketika peristiwa itu terjadi. Sementara itu, Tjetana Putra tinggal di Griya Jero Gede Sanur, rumah bangsawan dari kasta Brahmana yang berdiri pada dekade ke tujuh abad XVIII dan sangat dihormati di desanya. Hidupnya selalu berada di bawah kontrol keluarganya. Jika sampai terlambat pulang ke rumah, apalagi sampai malam, akan ada abdi yang datang mencari dan menjemputnya. Oleh karena itu, di zaman Revolusi Fisik, ia tidak berkompromi dengan tokoh-tokoh politik seperti halnya Ngurah Bagus dan Tangkas, melainkan dengan orang tuanya. Oleh karena itu, aktivitasnya hanya di sekitar desanya.

Namun karena di desanya juga banyak terdapat pemuda pejuang, maka mau tidak mau ia juga terseret dalam Revolusi Fisik dengan caranya sendiri. Tjetana Putra dan kawan-kawannya suka mengusili polisi NICA di pos penjagaannya. Tanpa disadari olehnya, ia telah memperkaya wacana peristiwa remeh-temeh sehari-hari (narasi kecil) Revolusi Fisik di Bali. Saat itu ia sudah duduk di kelas enam. Sekalipun ruang geraknya terbatas, semangat perjuangan yang diajarkan oleh Jepang masih membekas.

Di Pura Tanjung Sari ada dua pasang meriam besar peninggalan tentara Jepang. Satu pasang berada di sebelah utara Pura Tanjung Sari dan yang satu pasang lagi sebelah selatannya. Keempat moncong meriam itu diarahkan ke Desa Tangtu tempat Tjetana Putra dan saudarasaudaranya mengungsi menjelang pendaratan tentara Jepang di Sanur. Lokasi itu sangat strategis untuk menembak kapal perang tentara Sekutu yang akan mendarat di Tangtu. Lokasi keempat meriam itu berdekatan dengan bekas tangsi Jepang yang dibangun di atas tanah milik Griya Jero Gede Sanur.

Di areal tangsi Jepang itu masih banyak sisa mesiu. Tjetana Putra dan kawan-kawan terutama saat libur sekolah sering bermain-main dengan mesiu itu karena sangat suka mendengarkan ledakannya. Suatu saat, ia dan kawan-kawannya bereksperimen membuat mesiu itu menjadi roket, menyerupai mercon. Mesiu dibungkus dengan kertas koran, bagian ujungnya ditutup menyerupai tali mercon dan bagian belakangnya dibiarkan terbuka. Pada bagian ujungnya dibakar, setelah itu dilempar ke timur di atas permukaan laut. Roket kertas itu mengeluarkan api dan terbang tinggi ke udara. Tiba-tiba terdengar tembakan beruntun dari arah Asrama Polisi NICA. Ia dan kawan-kawannya terkejut mendengar tembakan beruntun itu dan mereka bersembunyi untuk menyelamatkan diri. Anggota polisi NICA mencoba mengejar untuk menangkap anak-anak itu, namun tidak berhasil karena mereka menghilang di balik rerimbunan pohon. Permainan itu dilakukan lebih dari empat kali dan tidak pernah tertangkap. Tjetana Putra dan kawan-kawannya saat itu memang sangat dipengaruhi oleh semangat pemuda revolusioner.

\section{Simpulan}

Hasil penelitian ini menunjukkan begitu banyak bentuk peristiwa remeh temeh sehari-hari di luar arena perang gerilya selama Revolusi Fisik di Bali yang bisa dipetik dari empat tokoh biografi kelahiran 1930-an. Peristiwa remeh temeh seharihari tersebut ditemukan dalam setiap babak Revolusi Fisik di Bali. Bentuknya sangat tergantung pada lokasi desanya dan pengalaman hidup tokohnya, dengan siapa dia bergaul dan apa yang mereka diskusikan atau pelajari dalam pergaulan itu.

Kajian ini mampu menarik simpulan bahwa ada relasi kuasa-pengetahuan dalam Revolusi Fisik di Bali. Sekalipun dalam Revolusi Fisik ditemukan begitu banyak simbol maupun tokoh-tokoh bangsawan kerajaan di dalamnya, namun keberadaan mereka tidak berpengaruh. Orang-orang terlibat dalam Revolusi Fisik di Bali tidak lagi terikat dengan masa lampaunya. Banyak sekali kejadian masa lampau di zaman kerajaan yang berbanding terbalik di zaman Revolusi Fisik. Tokoh yang leluhurnya merupakan bawahan dalam birokrasi kerajaan, memegang posisi yang strategis di masa Revolusi Fisik dan sebaliknya.

Demikian pula, pada pemuda usia belia, mereka tidak lagi berkompromi dengan masa lampau melainkan dengan peristiwa-peristiwa yang 
terdekat, yakni pergaulan dengan tokoh-tokoh politik, baik di lingkungan sekolah maupun di tempat tinggal. Jadi pada dasarnya, keterlibatan orang-orang dalam Revolusi Fisik di Bali merupakan hasil kompromi mereka dengan pengetahuan yang tersembunyi dalam wacana kemerdekaan termasuk pada pemuda belia usia 1115 tahun itu.

\section{Referensi}

Agung, I. A. A. G. (1993). Kenangan Masa Lampau Zaman Kolonial Hindia Belanda dan Zaman Pendudukan Jepang. Jakarta: Yayasan Obor Indonesia.

Ankersmit, F. R. (1987). Refleksi tentang Sejarah: Pendapat-Pendapat Modern tentang Filsafat Sejarah. Jakarta: PT. Gramedia.

Dwipayana, A. A. G. N. (2004). Bangsawan dan Kuasa: Kembalinya Para Ningrat di Dua Kota. Yogyakarta: IRE Press.

Foucault, M. (1980). Power/Knowledge, Colin Gordon, ed., trans. Colin Gordon, Leo Marshall, John Mepham, Kate Soper. Sussex: The Harvester Press.

Hilbery, R. (1979). Autobiographi Tjokorde Gde Agung Sukawati Ubud 1910-1978 as dictted to Rosemary Hilbery. Originally published as Reminiscences of a Balinese Prines Southeast Asian Paper No. 14 Southeast Asian Studies University of Hawai 1979.

Mirsha, I G. N. M., (Ed). (t.t.) Cokorda Alit Ngurah, Dari Pembuangan di Lombok sampai Revolusi Fisik di Bali (1907-1950. Pusat Dokumentasi Kebudayaan Bali.

Nordholt, H. S. (2006). The Spell of Power: Sejarah Politik Bali 1650-1940, Denpasar: Pustaka Larasan.

Pendit, N. S. (2008). Bali Berjuang. Denpasar: Pustaka Larasan.

Philpott, S. (2003). Meruntuhkan Indonesia: Politik Postkolonial dan Otoritarianisme, terjemahan Nuruddin Mhd. Ali, Uzair Fauzan. Yogyakarta: LKIS.

Pindha, I G. N. (2013). Perang Bali Sebuah Kisah Nyata. Jakarta: Dolphin.

Rabinow, P. (2012). Pengetahuan dan Metode Karya-karya Penting Foucault, terjemahan Arief. Yogyakarta: Adipura.
Ritzer, G. (2014). Teori Sosiologi Modern Edisi Ketujuh, terjemahan Triwibowo B.S. Jakarta: Kencana Prenada Media Group.

Robinson, G. (2006). Sisi Gelap Pulau Dewata: Sejarah Kekerasan Politik, terjemahan Arif B. Prasetyo. Yogyakarta: LKiS.

Wijaya, I. N. (2003). "Sang Sendi Dhamma: Biografi Sosial Bhante Thitaketuko Thera", Manuskrip.

Wijaya, I. N. (2012). Menerobos Badai: Biografi Intelektual Prof. Dr. I Gusti Ngurah Bagus. Denpasar: Pustaka Larasan.

Wijaya, I. N. (2014). "Ide Pedanda Dwija Ngenjung: Menyambung Tali Sejarah Griya Jero Gde Sanur." Manuskrip.

Wijaya, I. N. (2018). Bening Embun Perjalanan A.A. Made Djelantik: Putra Raja - DokterBudayawan. Denpasar: Pustaka Larasan.

Wirawan, A. A. B. (2012). Pusaran Revolusi Indonesia di Sunda Kecil 1945-1950. Denpasar: Udayana University Press.

\section{Daftar Informan}

Nyoman Sukiada

Ida Bagus Tantra

I Gusti Ngurah Made Pemecutan, pelukis Sidik Jari, di Denpasar pada 14 Februari 2017.

Nyoman Sukianda 